\title{
PREVALENCE OF PSYCHIATRIC DISORDERS AMONG FOLLOWERS VISITING FAITH HEALERS
}

\author{
Pankaj Kumar1, Ranjive Mahajan², Navkiran S. Mahajan³, Rupesh Chaudhary4, B. P. Mishra ${ }^{5}$
}

${ }^{1}$ Assistant Professor, Department of Psychiatry, Dayanand Medical College and Hospital, Ludhiana, Punjab, India. 2Professor and HOD, Department of Psychiatry, Dayanand Medical College and Hospital, Ludhiana, Punjab, India.

3 Professor, Department of Psychiatry, Dayanand Medical College and Hospital, Ludhiana, Punjab, India.

4 Professor, Department of Psychiatry, Dayanand Medical College and Hospital, Ludhiana, Punjab, India.

5Professor, Department of Clinical Psychology, Dayanand Medical College and Hospital, Ludhiana, Punjab, India.

\begin{tabular}{l}
\hline ABSTRACT \\
FACKGROUND \\
medicine in India. Although their role is not studied well in modern literature and their contribution is seen lightly in the light of \\
evidence-based medicine, this does not deter patients from seeking treatment from faith healers. The present study is conceived to \\
know the psychosocial characteristics of faith healers and followers.
\end{tabular}

\section{MATERIALS AND METHODS}

The observational study included 10 faith healers and their 100 followers. Both the groups were interviewed. They were assured of their confidentiality and informed written consent was taken. Demographic data was collected using a structured performa and 16 Personality Factor Questionnaire was used to know personality traits of followers as well as faith healers.

\section{RESULTS}

Female followers comprised 54\% of study sample. Majority of the subjects fell in the age group of 20-40 years irrespective of their sex. Mean age of study participants was 35.91 years. Two thirds of sample were married male/female. 53\% of the total subjects were Hindu and $44 \%$ of subjects were housewives belonging to low socio-economic status and low literacy. Sadness and unresponsiveness were the most common reasons of visit by the attendees. Personality profile of the followers reflects reserve and detached tendency with low emotional stability and low frustration tolerance. They are self-indulgent, conservative and follow traditional ideas. On the other hand, the faith healers were observed to have tough mindedness with realistic tendencies, conservative nature and tolerance of traditional ideas. The sample size estimation was also done at conveniences.

\section{CONCLUSION}

The role of social support system, method of traditional healing and the underlying implications for service delivery are important in the near future. The need of the followers should be understood by modern treatment strategies. However, further extensive studies may be required to establish the theoretical value of findings of this study.

\section{KEY WORDS}

Faith-Healers, Psychosomatic Problems, Personality.

HOW TO CITE THIS ARTICLE: Kumar P, Mahajan R, Mahajan NS, et al. Prevalence of psychiatric disorders among followers visiting faith healers. J. Evolution Med. Dent. Sci. 2019;8(02):129-132, DOI: 10.14260/jemds/2019/28

\section{BACKGROUND}

From time immemorial faith healing is practiced for bodily and mental wellbeing of patients in India. The practice of faith healing is invariably prevalent in most of the cultures and religions. Often there is turning towards faith healers due to strong religious faith and easy accessibility.

Faith healing practices have been easily available sources of healing for the people from a very long time, though this mode of treatment has been the least accepted by the general physicians or the psychiatrists. Not all, but people with a particular type of personality and income groups tend to seek the help of these faith healers before visiting a professional physician or a psychiatrist. Healers by virtue of their

'Financial or Other Competing Interest': None.

Submission 18-12-2018, Peer Review 05-01-2019,

Acceptance 07-01-2019, Published 14-01-2019.

Corresponding Author:

Dr. Rupesh Chaudhary,

Professor, Department of Psychiatry,

Dayanand Medical College and Hospital,

Ludhiana141001, Punjab, India.

E-mail: rupeshchaudhry123@yahoo.co.in

DOI: $10.14260 /$ jemds/2019/28 influence on the intimate lives of people occupy a pivotal position in every culture. Such a position ultimately becomes a strong motivating force. These incentives motivate them towards a career of healer. The motive according to them varied. Most of them offered their help without remuneration but grateful patients seldom failed to bring offerings. ${ }^{1}$ This behaviour of people is due to the cultural and social beliefs prevalent in the community. In order to understand the pattern of faith healing practices and people visiting faith healers, profiling of psychosocial factors is needed so as to know which type of people visit faith healers. Carstairs and Kapur conducted a study in a village regarding traditional healers and stated that they were well accepted by the community along with primary care physicians. ${ }^{2}$

Psychosomatic problems prevalent in community does not always seek solution from western medicine due to low income, time constraints and unavailability of modern methods. People tend to listen to traditional healers including ayurvedic physicians and religious practitioners. Studies regarding faith healers and their attendees are scarce in India although they are well received and respected by the community. 


\section{MATERIALS AND METHODS}

The observational study was conducted on faith healers and followers visiting those faith healers. A total of 10 faith healers and 100 followers were interviewed over a period of 18 months. Informed written consent was taken from the attendees and ethical approval was taken from institutional ethics committee. A semi-structured proforma was used for socio-demographic data and 16 Personality Factor Questionnaire ${ }^{3}$ was administered to both the groups. Student $t$ test was used to analyse the data. Since the duration of the study was less. The patients were selected by convenience sample technique.

\section{Statistical Analysis}

Data was collected and comparison was done and evaluated using Chi-square test and significance of $0.05 \quad(95 \%$ confidence interval) $(\mathrm{p}<0.05)$ was considered between the two groups and statistical analysis was done using SPSS software of Windows ver. 20.0.

\section{RESULTS}

\begin{tabular}{|c|c|c|c|c|c|c|c|c|c|c|}
\hline \multirow{3}{*}{ Age } & \multicolumn{5}{|c|}{ Followers (Gp-I) } & \multicolumn{5}{|c|}{ Faith healers (Gp-II) } \\
\hline & \multicolumn{2}{|c|}{$\begin{array}{c}\text { Male } \\
(\mathrm{N}=46)\end{array}$} & \multirow[t]{2}{*}{\begin{tabular}{|c|}
$\mathbf{P}$ \\
Value \\
\end{tabular}} & \multicolumn{2}{|c|}{$\begin{array}{l}\text { Female } \\
(\mathrm{N}=54)\end{array}$} & \multicolumn{2}{|c|}{$\begin{array}{c}\text { Male } \\
(\mathrm{N}=8)\end{array}$} & \multirow[t]{2}{*}{\begin{tabular}{|c|} 
P \\
Value \\
\end{tabular}} & \multicolumn{2}{|c|}{$\begin{array}{c}\text { Female } \\
(\mathrm{N}=2)\end{array}$} \\
\hline & $\dot{z}$ & o̊ & & $\dot{0}$ & वे & $\dot{2}$ & ᄋ : & & z & 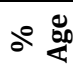 \\
\hline $20-40$ & 29 & 63.04 & 0.002 & 41 & 75.92 & 1 & 12.5 & 0.003 & 1 & 50 \\
\hline $41-60$ & 9 & 19.57 & 0.002 & 11 & 20.38 & 4 & 50 & 0.001 & 1 & 50 \\
\hline$>60$ & 8 & 17.39 & \begin{tabular}{|l|} 
\\
\end{tabular} .0011 & 2 & \begin{tabular}{|l|}
3.70 \\
\end{tabular} & 3 & 37.5 & 0.001 & 0 & 0 \\
\hline & & & & & & & & & & \\
\hline
\end{tabular}

\begin{tabular}{|c|c|c|c|c|}
\hline \multirow{2}{*}{ Marital Status } & \multicolumn{2}{|c|}{ Followers (Gp-I) } & \multicolumn{2}{c|}{ Faith Healers (Gp-II) } \\
\cline { 2 - 5 } & No. & \% Age & No. & \% Age \\
\hline Married & 67 & 67.00 & 8 & 80.00 \\
\hline Unmarried & 33 & 33.00 & 2 & 20.00 \\
\hline Z-Value & 4.81 & & & \\
\hline p-Value & 0.0053 & & & \\
\hline \multicolumn{5}{|c|}{ Occupation } \\
\hline Business & 4 & 4.00 & 0 & 0.00 \\
\hline Farming & 7 & 7.00 & 1 & 10.00 \\
\hline Service & 5 & 5.00 & 0 & 0.00 \\
\hline Shop Keeping & 4 & 4.00 & 0 & 0.00 \\
\hline Labour & 18 & 18.00 & 0 & 0.00 \\
\hline Ex-Service & 3 & 3.00 & 0 & 0.00 \\
\hline Studies & 15 & 15.00 & 0 & 0.00 \\
\hline Housewife/Nil & 44 & 44.00 & 9 & 90.00 \\
\hline \multicolumn{5}{|c|}{ Education } \\
\hline Illiterate & 0 & 0.00 & 3 & 30.00 \\
\hline $\begin{array}{c}\text { Up to 8th } \\
\text { Standard }\end{array}$ & 64 & 64.00 & 5 & 50.00 \\
\hline 9th - 10+2 & 28 & 28.00 & 2 & 20.00 \\
\hline Graduate & 8 & 8.00 & 0 & 0.00 \\
\hline \multicolumn{7}{|c|}{ Mean } & $7.95 \pm$ & $4.40 \pm 3.81$ & & \\
\hline Table 2. Distribution of Subjects According to Their Marital \\
Status, Occupation and Educational Status \\
\hline
\end{tabular}

\begin{tabular}{|c|c|c|}
\hline Reason & No. & \% Age \\
\hline Unexplained Ghabrahat/Sadness & 29 & 29.00 \\
\hline Unresponsiveness & 25 & 25.00 \\
\hline Headache/Backache & 16 & 16.00 \\
\hline Alco/Drug with Sadness & 13 & 13.00 \\
\hline Affair Brake & 4 & 4.00 \\
\hline Religious Purpose & 4 & 4.00 \\
\hline Breathlessness & 2 & 2.00 \\
\hline Repeated worry & 2 & 2.00 \\
\hline
\end{tabular}

\begin{tabular}{|c|c|c|}
\hline Disorganized Behaviour & 1 & 1.00 \\
\hline Itching & 1 & 1.00 \\
\hline Over Talkative & 1 & 1.00 \\
\hline Repeated Thinking & 1 & 1.00 \\
\hline Repeated Checking & 1 & 1.00 \\
\hline Table 3. Reasons for Visiting Faith Healers by The Respondents \\
\hline
\end{tabular}

Table 3. Reasons for Visiting Faith Healers by The Respondents

\begin{tabular}{|c|c|c|c|c|c|c|}
\hline $\begin{array}{c}\text { Personality } \\
\text { Traits }\end{array}$ & Followers & \multicolumn{2}{c|}{$\begin{array}{c}\text { Faith } \\
\text { Healers }\end{array}$} & t-Value & p-Value \\
\hline & Mean & SD & Mean & SD & & \\
\hline A & 3.84 & 1.18 & 6.70 & 1.64 & 7.04 & $0.0023^{* *}$ \\
\hline B & 4.77 & 1.40 & 4.20 & 1.69 & 1.20 & 0.1369 \\
\hline C & 3.46 & 1.37 & 6.00 & 1.05 & 5.69 & $0.0029^{*}$ \\
\hline E & 6.09 & 1.30 & 4.20 & 0.63 & 4.53 & $0.0036^{*}$ \\
\hline F & 4.82 & 1.65 & 4.70 & 2.54 & 0.21 & 0.7942 \\
\hline G & 3.88 & 1.77 & 6.60 & 0.52 & 4.82 & $0.0034^{*}$ \\
\hline H & 4.77 & 1.95 & 6.90 & 0.99 & 3.40 & $0.0048^{*}$ \\
\hline I & 6.61 & 1.92 & 2.60 & 1.58 & 6.38 & $0.0025^{* *}$ \\
\hline L & 5.81 & 1.41 & 7.30 & 2.36 & 2.97 & $0.0055^{*}$ \\
\hline M & 4.09 & 1.61 & 4.60 & 1.26 & 0.97 & 0.1699 \\
\hline N & 4.88 & 1.52 & 4.10 & 1.20 & 1.57 & 0.1049 \\
\hline O & 5.78 & 1.66 & 6.90 & 0.74 & 2.11 & 0.0391 \\
\hline Q1 & 3.53 & 1.89 & 2.70 & 0.67 & 1.38 & 0.1199 \\
\hline Q2 & 4.94 & 1.73 & 9.10 & 1.20 & 7.41 & $0.0022^{* *}$ \\
\hline Q3 & 6.51 & 1.73 & 8.20 & 0.63 & 3.06 & $0.0053^{*}$ \\
\hline Q4 & 6.86 & 1.81 & 7.20 & 2.30 & 0.55 & 0.2986 \\
\hline Table 4. Comparison of Different Personality Traits of \\
\hline \multicolumn{7}{|c|}{ Followers and Faith Healers } \\
\hline *-- significant at 0.05, ** highly significant at 0.01 level \\
\hline
\end{tabular}

\begin{tabular}{|c|c|c|c|c|c|}
\hline Traits & Total & Male & Fe & $\begin{array}{c}\mathrm{t}- \\
\text { Value }\end{array}$ & p-Va \\
\hline $\begin{array}{c}\text { A } \\
\text { (Warmth) }\end{array}$ & & & & 16 & 0382* \\
\hline $\begin{array}{c}\mathrm{B} \\
\text { (Reasoning) } \\
\end{array}$ & $\begin{array}{c}.77 \pm \\
.40 \\
\end{array}$ & $\begin{array}{c}4.52 \pm \\
1.31 \\
\end{array}$ & $\begin{array}{c}4.98 \pm \\
1.45 \\
\end{array}$ & .65 & 0.09 \\
\hline $\begin{array}{c}\mathrm{C} \\
\text { (Emotional } \\
\text { stability) }\end{array}$ & $\begin{array}{c}3.46 \pm \\
1.37\end{array}$ & $\begin{array}{c}3.83 \pm \\
1.52\end{array}$ & $\begin{array}{c}3.15 \pm \\
1.14\end{array}$ & 2.55 & 0.032 \\
\hline $\begin{array}{r}\mathrm{E} \\
\text { (Domin } \\
\end{array}$ & & & & 2.03 & $0.0406^{*}$ \\
\hline $\begin{array}{c}\mathrm{F} \\
\text { (Liveline }\end{array}$ & $\begin{array}{c}4.82 \pm \\
1.65\end{array}$ & $\begin{array}{l}4.61 \pm \\
1.72\end{array}$ & $\begin{array}{c}5.00 \pm \\
1.58\end{array}$ & 1.18 & 0.1397 \\
\hline $\begin{array}{c}\mathrm{G} \\
\text { (Rule- } \\
\text { consciousness) } \\
\end{array}$ & $\begin{array}{c}3.88 \pm \\
1.77\end{array}$ & $\begin{array}{c}3.59 \pm \\
1.76\end{array}$ & $\begin{array}{l}3 \pm \\
76\end{array}$ & 1.53 & 0.1 \\
\hline $\begin{array}{r}\mathrm{H} \\
\text { (Social Bol }\end{array}$ & \begin{tabular}{|c|}
$4.77 \pm$ \\
1.95 \\
\end{tabular} & $\begin{array}{c}4.70 \pm \\
1.98 \\
\end{array}$ & & 0.33 & 0.5001 \\
\hline $\begin{array}{c}\text { I } \\
\text { (Sensitiv } \\
\end{array}$ & & & & 1.35 & 0.1220 \\
\hline $\begin{array}{c}\mathrm{L} \\
\text { (Vigilan } \\
\end{array}$ & \begin{tabular}{|c|}
$5.81 \pm$ \\
1.41 \\
\end{tabular} & & $\begin{array}{l}3 \pm \\
35\end{array}$ & .38 & O. \\
\hline $\begin{array}{c}\mathrm{M} \\
\text { (Abstracted } \\
\end{array}$ & $\begin{array}{c}4.09 \pm 1 \\
.61 \\
\end{array}$ & $\begin{array}{c}4.41 \pm \\
1.87 \\
\end{array}$ & $\begin{array}{c}3.81 \pm \\
1.30 \\
\end{array}$ & 1.88 & 0.0875 \\
\hline $\begin{array}{c}\mathrm{N} \\
\text { (Privaten }\end{array}$ & $\begin{array}{c}4.88 \pm . \\
152 \\
\end{array}$ & & & 0.72 & 0.2298 \\
\hline $\begin{array}{c}0 \\
\text { (Apprehension) } \\
\end{array}$ & \begin{tabular}{|c|}
$5.78 \pm$ \\
1.66 \\
\end{tabular} & $\begin{array}{c}5.57 \pm \\
1.72 \\
\end{array}$ & $\begin{array}{c}5.96 \pm \\
1.60 \\
\end{array}$ & 1.17 & 0.1700 \\
\hline $\begin{array}{c}\mathrm{Q1} \\
\text { (Openness to } \\
\text { change) }\end{array}$ & $\begin{array}{c}3.53 \pm \\
1.89 \\
\end{array}$ & $\begin{array}{c}3.46 \pm \\
1.85 \\
\end{array}$ & $\begin{array}{c}3.59 \pm \\
1.94 \\
\end{array}$ & 0.34 & 0.4836 \\
\hline $\begin{array}{c}\mathrm{Q} 2 \\
\text { (Self-reliance) }\end{array}$ & \begin{tabular}{|c|}
$4.94 \pm$ \\
1.73 \\
\end{tabular} & $\begin{array}{c}5.09 \pm \\
1.91 \\
\end{array}$ & $\begin{array}{c}4.81 \pm \\
1.58 \\
\end{array}$ & 0.80 & 0.2 \\
\hline Q3 & \begin{tabular}{|c|}
$6.51 \pm$ \\
1.73 \\
\end{tabular} & $\begin{array}{c}6.35 \pm \\
1.90 \\
\end{array}$ & $\begin{array}{c}6.65 \pm \\
1.58 \\
\end{array}$ & 0.86 & 0.1913 \\
\hline $\begin{array}{c}\mathrm{Q} 4 \\
\text { (Tension) } \\
\end{array}$ & \begin{tabular}{|c|}
$6.86 \pm$ \\
1.81 \\
\end{tabular} & $\begin{array}{c}6.91 \pm \\
1.77 \\
\end{array}$ & $\begin{array}{c}6.81 \pm \\
1.86 \\
\end{array}$ & 0.27 & 0.6022 \\
\hline \multicolumn{6}{|c|}{$\begin{array}{c}\text { Table 5. Comparison of Personality Traits of Male and } \\
\text { Female Subjects }\end{array}$} \\
\hline
\end{tabular}


The age wise distribution of both groups (followers and faith healers) in table 1 shows that the maximum number of followers were in age group of 20-40 years followed by the age group $41-60$ years which consisted of $70 \%$ and $20 \%$ respectively whereas only $10 \%$ of followers were in the age group $>60$ years with mean age $35.91 \pm 14.59$ whereas in faith healers the age group of $41-60$ with mean age $50.10 \pm$ 12.22 were prominent. Table also reveals that more number of females visiting to faith healers than males $(75.92 \%$ and $63.04 \%$ respectively (Table 1 ).

Out of 100 followers studied, it was observed that $44 \%$ were house wives or non-working without any income where as $90 \%$ of faith healers were having only faith healing as profession, no other source of income for them. On the basis of their education, majority (64\%) of followers and $50 \%$ of faith healers were educated up to $8^{\text {th }}$ standard. (Table 2).

Majority of followers were visiting to faith healers with one or other psychiatric symptoms (83\%) out of which unexplained ghabrahat, restlessness and sadness were major symptoms. (Table 3).

The results of personality assessment using 16 PF show that majority of followers fall on low score distribution side for factors $\mathrm{A}$, factor $\mathrm{C}$, factor $\mathrm{G}$, and factor Q1 (3.84 \pm 1.18 ; $3.46 \pm 1.37 ; 3.88 \pm 1.77$ and $3.53 \pm 1.89$ respectively) which reflects reserve and detached tendency with low emotional stability and low frustration tolerance. They are selfindulgent, conservative and follow traditional ideas. The high score traits were observed for factor I, factor Q3, factor Q4 $(6.61 \pm 1.92,6.51 \pm 1.73,6.86 \pm 1.81$ respectively $)$ which reflects their tender minded, dependent and sensitive tendencies with socially precise and high ergic tension. The overall profile shows that the followers are introverted dependent personality. They are prone to frustration and anxiety. They are also self-indulging and conservative in nature. On the other hand, faith healers were observed to have significantly low score on Q1 and I factors (2.70 \pm 0.67 , $2,60 \pm 1.58$ ) which reflects their tough minded and realistic tendency with conservative nature and tolerance of traditional ideas. They have high score on factor $\mathrm{A}$, factor $\mathrm{G}$, factor $\mathrm{H}$, factor $\mathrm{L}$, factor $\mathrm{O}$, factor $\mathrm{Q} 2$, and factor $\mathrm{Q} 3$ (6.70 \pm $1.64,6.60 \pm 0.52,6.90 \pm 0.99,7.30 \pm 2.36,6.90 \pm 0.74,9.10 \pm$ $1.20,7.20 \pm 2.30$ ), the traits reflected on these factors are extrovert, moralistic, rule bound, bold, venturesome, sceptical, and suspicious. They are hard to fool, and also socially very precise. They also show some degree of apprehension and worrying tendency. They are controlled, resourceful and prefer own decisions. The overall protocol of faith healers shows extrovert, easy going personality but excessively moralistic and rule bound (Table 4).

There are statistically significant differences between personality of male followers and female followers on factors $\mathrm{A}$, factor $\mathrm{C}$ and factor $\mathrm{E}(4.11 \pm 1.10$ vs $3.61 \pm 1.20,3.83 \pm 1.52$ vs $3.15 \pm 1.14,6.37 \pm 1.27$ and $5.85+1.28$ ) which reflects that female followers are more reserved, more vulnerable to emotional conditions and more submissive and more easily led than the male followers. Both the sexes show low frustration tolerance. The other factors on $16 \mathrm{PF}$ protocol shows no significant difference (Table 5).

\section{DISCUSSION}

The faith healer occupies a unique and prestigious position in the society due to easy availability. This relates to the wide acceptance of traditional modalities by a large number of people, both for psychiatric and non-psychiatric problems. People consult healers because of a belief that the healers are 'gifted' with 'magical-skills'. They therefore occupy a very important position in our society (Sethi et al). ${ }^{4}$ In the present study, the maximum followers were in the age group of 20-40 yrs. with the mean age of 35 (predominantly females) and the faith healers were in the age group of 41-60 yrs. (predominantly males) where as other studies like Sethi et $\mathrm{al}^{4}$ and Trivedi et $\operatorname{al}(1980)^{5}$ reported more female followers visited faith healers than the same age group male counterparts. Though study conducted by Farooqi ${ }^{6}$ found more males among the followers visiting these faith healers. These different help-seeking practices were attributed to gender discrimination in mobility and taboos attached to women's consultation of male traditional healers. Education appears an important factor for the followers. In the present study, married individuals both males and females visiting these faith healers were of low education level ( $8^{\text {th }}$ std.). Ngoma et $\mathrm{al}^{7}$ and Satija et al $(1981)^{8}$ reported opposite findings. They reported better educated and employed group of people visiting the faith healers. This could be due to culture difference or some bias in selection of faith healers.

The most common reasons for visiting the faith healers were found to be sadness, ghabrahat, unresponsiveness at times and headache. The study conducted by Shai-Mahoko ${ }^{9}$ reported that people with problems like infertility, impotence, sexually transmitted diseases etc., were visiting these healers more frequently than the general population. All these symptoms require sometime to become symptoms free. Since followers have low frustration tolerance and seek immediate relief from symptoms, they rush to faith healers for some miracles. Similar reasons were reported by Sethi et al, ${ }^{4}$ Ngoma et al ${ }^{7}$ and Sharma et al (2007).10

The study also reflected the interesting traits of followers as tender minded, dependent, and sensitive personality traits which makes them vulnerable to get influenced by strong and opposite personality traits. This finding is new since only one study used structured Personality Test. In a study by Pattison, who reported in this regard typical constellation of personality traits, including the use of denial, repression, projection, and disregard of reality. ${ }^{11}$ In a study done among tuberculosis patients, majority of patients were emotionally labile, affected by feelings, submissive in nature and tender minded. Followers appear to be significantly introvert, detached and conservative. They are self-indulging and vulnerable to stress since their frustration tolerance is very low as reported by Chaudhary et al.12 Psycho dynamically it is commonly understood that persons with insecurity, more repressed and unfulfilled desires and traumatic experiences deeply rooted in pathological familial interactions with repressed hostility and feeling of sin or guilt are more vulnerable for suggestive practices (Satija et al).13

Faith healers are successful enough to convince the followers that they are the right kind of people to relieve them of their uncontrolled and unexplained problems. The faith healers use various methods to convince these followers like giving tabiz, scarification, witch-crafting, many rituals and spiritual performances etc. Though in the light of modern medical treatments, the methods opted by these faith healers 
might appear bizarre and inappropriate, but they succeed more due to their communication skills.

One of the major limitations of the study was that the exact outcome of the followers was not studied as they were not followed back for further assessment. This can give us the insight regarding the basis of their belief. Our study was primarily quantitative whereas qualitative study may have unveiled other aspects of this problem.

\section{CONCLUSION}

It can be concluded that in view of the vast prevalence of the people seeking these healing practices, it could be said that behavioural scientists should put an effort to incorporate good communication skills \& detailed explanation to the sufferers with indigenous style of explanation. The role of social support system, concept of traditional healing and the underlying implications for service delivery are important so that the psychosocial needs of the followers can be understood in a better way. However further extensive studies may be required to establish the theoretical and clinical value of our findings in this work. The results of our study support the need of indigenous concept, better social awareness regarding scientific and evidence-based modalities of treatment of their problems.

\section{Limitation of the Study}

Due to short duration of study, sample size was also calculated by convenience. The results of the study cannot be generalised due to the potential bias and sample size estimation.

\section{REFERENCES}

[1] Trivedi JK, Sethi BB. A psychiatric study of traditional healers in Lucknow city. Indian J Psychiatry 1979;21(2):133-7.

[2] Carstairs GM, Kapur RL. The great universe of Kota: stress, change and mental disorder in an Indian village. London: Hogarth Press 1976.
[3] Cattell RB, Cattell AK, Cattell HE. 16PF Fifth edition Questionnaire. Champaign: Institute for Personality and Ability Testing 1993.

[4] Sethi BB, Trivedi JK. Socio-demographic variables and manifestation of ill health of patients who attended traditional healers' clinic. Indian J Psychiatry 1979;21(1):46-50.

[5] Trivedi JK, Sethi BB. Healing practices in psychiatry patients. Indian J Psychiatry 1980;22(1):111-6.

[6] Farooqi YN. Traditional healing practices sought by Muslim psychiatric patients in Lahore, Pakistan. International J Disability, Development and Education 2006;53(4):401-15.

[7] Ngoma MC, Prince M, Mann A. Common mental disorders among those attending primary health clinic and traditional healers in urban Tanzania. $\mathrm{Br} \mathrm{J}$ Psychiatry 2003;183:349-55.

[8] Satija DC, Singh D, Nathawal SS, et al. A psychiatric study of patients attending Mehandipur balaji temple. Indian J Psychiatry 1981;23(3):247-50.

[9] Shai-Mahoko SN. Indigenous healers in the North West province: a survey of their clinical activities in health care in the rural areas. Curationis 1996;19(4):31-4.

[10] Sharma P, Vohra AK, Khurana H. Treatment seeking behavior of mentally ill patients in a rural area: a cross sectional study. Indian J Comm Med 2007;32(4):290-1.

[11] Pattison EM, Lapins NA, Doerr HA. Faith healing: a study of personality and function. Journal of Nervous and Mental Disease 1973;157(6):397-409.

[12] Chaudhri S, Bansal A, Singh A, et al. Impact of psychiatric profile and personality trait on directly observed tuberculosis treatment outcome. International Journal Medicine and Public Health 2013;3(4):303-8.

[13] Satija DC, Nathawat SS, Singh D, et al. A study of patients attending Mehandipur balaji temple: psychiatric and psychodynamic aspects. Indian J Psychiatry 1982;24(4):375-9. 